\title{
Legers alkoholvaner i endring
}

Legers alkoholbruk er økt de siste årene, men de drikker seg sjeldnere beruset.

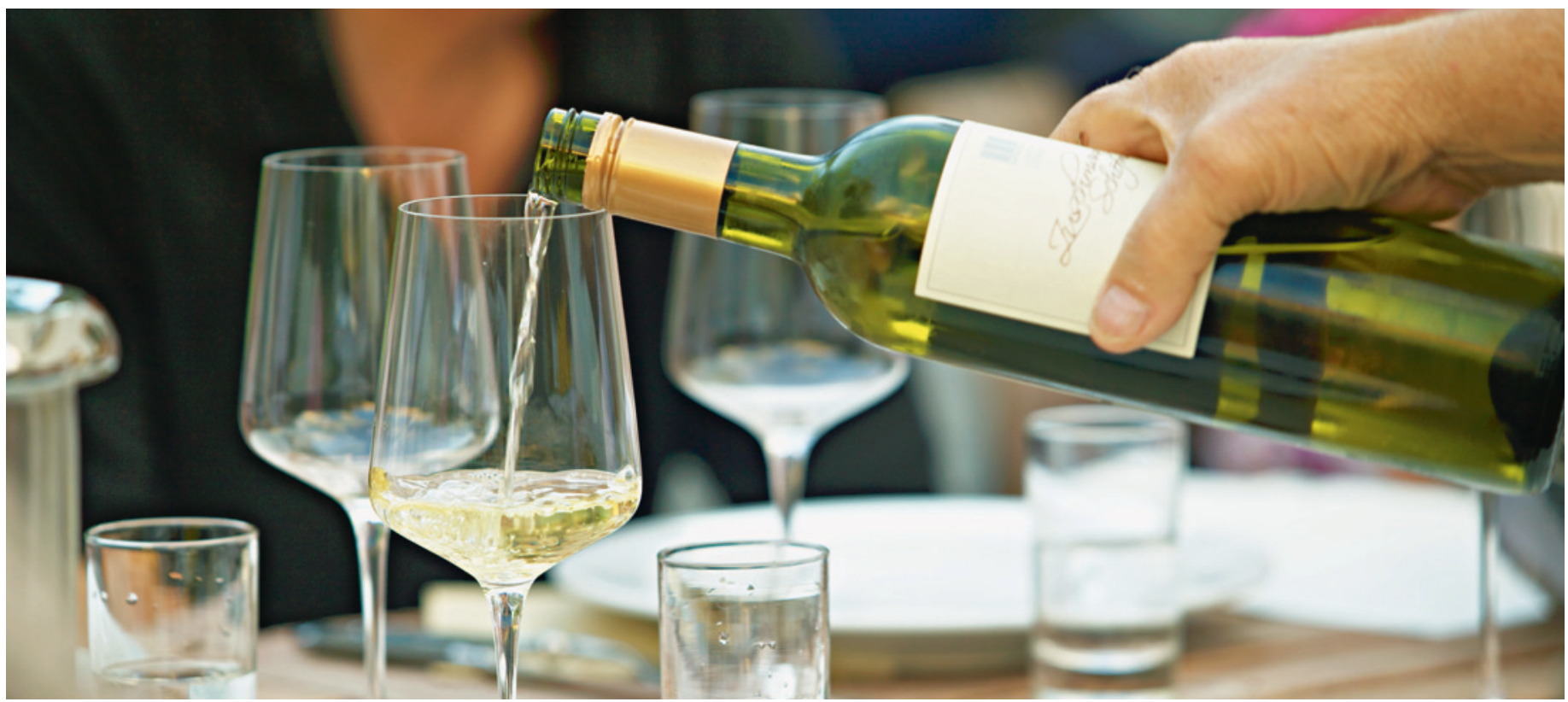

Illustrasjonsfoto: NTB scanpix

Alkoholbruk er en livsstilsfaktor med stor betydning for folkehelsen. Legene spiller en sentral rolle i å fremme en sunn livsstil. Hvor mye en lege interesserer seg for alkoholrelaterte problemer hos sine pasienter, avhenger av flere faktorer, blant annet legens egne drikkevaner. Leger med moderat alkoholbruk har større sannsynlighet for å snakke med pasientene om alkohol enn leger med høyt alkoholkonsum (1). Siden alkoholvaner endrer seg over tid, er regelmessig vurdering av alkoholatferd en viktig del av pasientvurderingen.

I en studie basert på Legeforskningsinstituttets legepanel har vi med kartleggingsverktøyet AUDIT (Alcohol Use Disorders Identification Test) sett på norske legers alkoholatferd i 2000 og 2010 (2). Vi fant en signifikant økning i moderat alkoholbruk og samtidig en signifikant nedgang $\mathrm{i}$ «drikking til beruselse» og negative konsekvenser av alkohol, som blackout eller skader på seg selv eller andre.

Det er antakelig flere forklaringer på dette. Holdninger til alkohol er nær forbundet med livsstilstrender i samfunnet og kultur på arbeidsplassen, inkludert kjønnsfordeling. Det er større sannsynlighet for alkoholbruk og alkoholrelaterte problemer hos kvinner og menn på en mannsdominert arbeidsplass enn på en kvinnedominert arbeidsplass (3). Dette bekreftes i studier av leger, der vi tidligere har vist at kvinnelige og mannlige leger i kirurgiske spesialiteter drikker mer risikofylt enn leger fra ikke-kirurgiske spesialiteter $(4,5)$. Det er ikke umulig at den økende kvinneandelen på disse arbeidsplassene bidrar til nedgang i risikofylt alkoholbruk.

En annen grunn til sunnere drikkemønster blant norske leger kan være nye livsstilstrender. Personer med høyere utdanning, og i noen grad yngre mennesker, er mer mottakelige for nye vaner, inkludert alkoholvaner (6). En analyse av franske husholdninger viser for eksempel at slike endringer, som kalles «moderniseringsprosesser», starter i den høyt utdannede delen av befolkningen (7). Det er mulig at drikkemønsteret til norske leger er blitt «modernisert» og følger en internasjonal trend med hyppigere drikking, men sjeldnere drikking til beruselse.

Utviklingen i alkoholatferd blant leger er gunstigere enn i befolkningen for øvrig, hvor det er observert en økning i drikking og samtidig en stabilitet i drikking til beruselse fra 1995 til 2008 (8). Andelen som skåret for et risikofylt alkoholkonsum var $7 \%$ blant leger i 2010 (AUDIT-skår > 8), mot rundt $17 \%$ i befolkningen i 2012-13 (AUDITskår $\geq 8)(9)$.

\section{Judith Rosta}

judith.rosta@legeforeningen.no
Judith Rosta (f. 1968) er seniorforsker ved Legeforskningsinstituttet (LEFO), Den norske legeforening.

Litteratur

1. Frank E, Elon L, Naimi T et al. Alcohol consumption and alcohol counselling behaviour among US medical students: cohort study. BMJ 2008; 337: a2155.

2. Rosta J, Aasland OG. Changes in alcohol drinking patterns and their consequences among Norwegian doctors from 2000 to 2010: a longitudinal study based on national samples. Alcohol Alcohol 2013; 48: 99-106

3. Plant ML, Plant MA, Foster J. Alcohol, tobacco and illicit drug use amongst nurses: a Scottish study. Drug Alcohol Depend 1991; 28: 195-202.

4. Rosta J, Aasland OG. Female surgeons' alcohol use: a study of a national sample of norwegian doctors. Alcohol Alcohol 2005; 40: 436-40.

5. Rosta J. Hazardous alcohol use among hospital doctors in Germany. Alcohol Alcohol 2008; 43: 198-203.

6. Hupkens CL, Knibbe RA, Drop MJ. Alcohol consumption in the European community: uniformity and diversity in drinking patterns. Addiction 1993 88: $1391-404$.

7. Sulkunen P. Drinking in France 1965-1979. An analysis of household consumption data. $\mathrm{Br} J$ Addict 1989: 84: 61-72.

8. Østhus S, Bye EK, Storvoll EE. Alkoholkonsum. I: Skretting A, Storvoll EE, red. Utviklingen på rusmiddelfeltet. Oslo: SIRUS, 2011: 82-95.

9. Halkjelsvik T, Storvoll EE. Andel av befolkningen i Norge med et risikofylt alkoholkonsum målt gjennom Alcohol Use Disorders Identification Test (AUDIT). Nordic Studies on Alcohol and Drugs 2014; $31: 1-11$ 